\title{
UTILIZATION OF FILM GENRE AS PRIOR TEXT STUDY IN TITLE WRITING OF STUDENT CREATIVITY PROGRAM
}

\author{
Nivia Putri Ratna Juwita ${ }^{1}$, Atiqa Sabardila², \& Markhamah $^{3}$

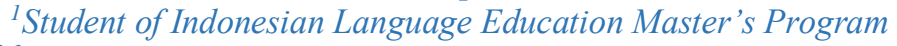 \\ ${ }^{2,3}$ Lecturer of Indonesian Language Education Master's Program \\ Faculty of Teaching and Education \\ Universitas Muhammadiyah Surakarta
}

\begin{tabular}{l}
\hline ARTICLE INFO \\
\hline Received: 14-07-2020 \\
Accepted: 10-10-2020 \\
Published: 12-10-2020 \\
Volume: 4 \\
Issue: 2 \\
DOI: \\
https://doi.org/10.33019/lire.v3 \\
i2.86 \\
\hline KEYWORDS \\
film genre, prior text, Student \\
Creativity Program title
\end{tabular}
\begin{abstract}
This study aims to describe the relationship of intertextuality between the titles of Student Creativity Program (SCP) with film genres. This research is in the form of qualitative descriptive research that is naturalistic in character. The data source used in this study originates from 5 fields of SCP funded in 2018. Data collection is performed in the form of words, phrases, clauses, and sentences through document study. Observation and note-taking techniques are utilized to collect data. The method of data analysis uses translational identity, referential identity, and abductive inferences. The referential identity method is used to identify the relationship of intertextuality in the writing of the SCP titles and film genres. Intertextual study is carried out comprehensively, by finding similarities and differences between the two. Furthermore, the abductive inferences method is utilized to draw conclusions. The data validity test uses theory triangulation. Based on data analysis, it can be concluded that the relationship of intertextuality contained in the SCP titles involves three film genres: (1) animation; (2) drama; and (3) horror. The results of this study indicate that the use of film genres of animation and drama genres as reference texts has high appeal in the writing of the titles of SCP.
\end{abstract}

\section{INTRODUCTION}

Student Creativity Program (SCP) or Program Kreativitas Mahasiswa (PKM) is a program from the Directorate General of Learning and Student Affairs of the Ministry of Research, Technology, and Higher Education of the Republic of Indonesia to facilitate the potentials of Indonesian students to study, develop, and apply the knowledge and technology they have learned in lectures to the community. Students send proposals of their creative programs to be chosen for grants.

A key element of the proposal of SCP is the title, which process of writing is generally carried out in interesting ways, an effort aimed at presenting the contents of the program itself and producing the effect of reading appeal. The appeal can originate from various factors, one of which is from the intertextuality relationship that utilizes the film genre as a reference text in the writing of the titles. This study aims to explain the intertextuality relationship in the titles with the film

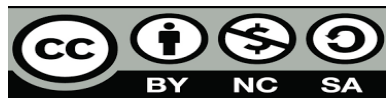

This work is licensed under Creative Commons Attribution-ShareAlike 4.0 Internasional. Copyright (C) 2020, Nivia Putri Ratna Juwita1, Atiqa Sabardila2, \& Markhamah 
genres, which are used as an inspiration for the writers in making the titles. This research will prove that texts in the SCP titles are present by carrying the influence from other texts.

Some researches related to prior text (intertextuality) have been conducted before. The striking difference with this research is in the source of the data used; henceforth the results obtained will also contain differences. Previous researches utilized poetry, music albums, diversity texts, humor texts, story texts, ideologies, novels, and videos as data sources. This study is important to conduct because it will enrich the knowledge base involving the creation of linguistically engaging titles, specifically ones that involve intertextuality as an element of language.

\section{LITERATURE REVIEW}

Student Creativity Program (SCP) is part of an effort to shape character, creative thinking skills, and act of students. One of the highlights in the preparation of SCP is the creativity of the writer in making the title. (Wafi, 2019) states that creativity is interpreted as the ability to create something new by providing fresh new ideas. Some views call prior text as intertextuality. The prior text that inspired or influenced the present text is called intertextuality (Kristeva, 1980: 55; Beugrande (2006: 39). Each new text is never completely sterile from the existence of other texts (Hasbullah, 2014). Creation of the present texts requires background knowledge of pre-existing texts.

The characteristic of intertextuality is the dependence of one text to pre-existing texts in the form of crosses of various expressions and quotations that complement each other (Piliang, 2006: 16). This is not stated as a distortion in the writing of a text (A. Teeuw, 1984: 120). (Fiske, 1987) classifies intertextuality into two, namely horizontal intertextuality and vertical intertextuality. Horizontal intertextuality is a variant of intertextuality that takes place at the same level or at an equal level. Second, vertical intertextuality is intertextuality which shows the existence of relationships or interactions in different types of references. 


\section{METHODOLOGY}

\subsection{Data}

The data source originates from 5 fields of Student Creativity Programs (SCP) funded in 2018. Data collection in the form of words, phrases, clauses, and sentences is carried out with document studies, which utilize the observation and note taking techniques to collect data. Research data is in the form of prior text that refers to the film genre of: (1) animation; (2) drama; and (3) horror, which presence already exist beforehand.

\subsection{Method}

This research is a type of qualitative descriptive research that is naturalistic (Sugiyono, 2012: 14). Methods of data analysis use translational identity, referential identity, and abductive inferences. The referential identity method is used to identify the relationship of intertextuality in the writing of the 5 titles with film genre. Intertextual study is carried out comprehensively, by finding similarities and differences between the two. Furthermore, the abductive inferences method is utilized to draw conclusions (Krippendorff, 2004). The data validity test used in this study is the triangulation theory.

\section{RESULTS AND DISCUSSION}

\subsection{Result}

Film is a work of art that is closely related to people's lives or referred to as social institutions (Susanti \& Raharja, 2017). Various forms of genre and variations in film have their own appeal for film lovers (Efendi P., 2009). The attractiveness of film is observed in the study in relation to the intertextual relationship in the Students Creativity Program (SCP) titles, which places the film genre as a source of inspiration or reference text. The results showed the use of film genres: (1) animation; (2) drama; and (3) horror, as the reference texts. The following are examples that show the genres of film being used as prior texts in the title of SCP programs.

\subsubsection{Prior Text from Animation Genre}

Some animated films are used as inspiration for writers in making the SCP titles. It aims to provide appeal to the title. It is known that animated films have an appeal because they present messages in the form of motion and audio that gives an impression to the audience. Interesting animated characters make animated films easy for children to like (Purwanto \& Yuliana, 2016). Writing the

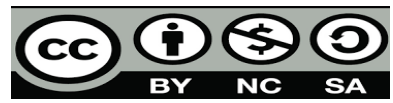


title of the film well is also an attraction of a visual image by providing its own perception for the audience (Kartika \& Riyadi, 2011). The relationship between intertextuality in SCP and animation film titles lies in the similarity in the use of the title and the content that is carried. Here are some animated films that are used as prior texts in the writing of SCP titles.

\section{(1) PIKACHU "Pizza Kacang Hijau Untuk Anak Autis dan ADHD" (071012/2018/PKMK)}

In the title of SCP data (1), it is clear that there is a connection between the title of SCP and one of the children animated films, Detective Pikachu, which was released in 2016 ${ }^{1}$. The film was made with an initial concept inspired by the TV series and video game series created by Nintendo in 1995, namely Pokemon ${ }^{2}$. The choosing of the title refers to the innovation of nutritious foods for children with autism and ADHD. Children with special needs need important attention in choosing good nutrition for them. Foods to avoid are foods that are free of gluten and casein. This innovation comes as an answer to providing snacks that are able to steal the attention of children with autism and ADHD because it is attractive and have the nutritional content they need. This snack is called PIKACHU, which stands for pizza kacang hijau (green bean pizza) ${ }^{3}$.

Presentation of the pizza was made interesting to get the attention of children, especially children with special needs. They are known to have difficult eating patterns. (Kesuma, Novayelinda, \& Sabrian, 2015) states that child behavior that is difficult to feed is a phase of eating behavior that is commonly found in children. This is caused by factors of parental eating behavior, food supply, and food control, as well as children's involvement. So the presentation of food in an attractive form would certainly be a solution to the problem. Such is the case with an interesting snack innovation called PIKACHU in data (1) above.

The naming of the food was inspired by one of the pre-existing animated films that are popular with children, Detective Pikachu. (Sukyadi, 2013) states that something that is created by someone whether directly or indirectly influenced by the ideas or thoughts of others, is called

\footnotetext{
${ }^{1}$ https://id.wikipedia.org/wiki/Pok\%C3\%A9mon:_Detective_Pikachu on March 312020 at 10.30 Western Indonesian Time

2 https://id.wikipedia.org/wiki/Pok\%C3\%A9mon on March 312020 at 10.35 Western Indonesian Time

${ }^{3}$ https://jatim.sindonews.com/read/298/3/pikachu-makanan-bergizi-ternyata-cocok-untuk-anak-autis-dan-adhd-1533362911 on March 31 2020 at 11.01 Western Indonesian Time
} 
intertextuality. The selection of children's animated film figure serves to provide attraction or give a certain impression on children with autism and ADHD to want to consume snacks that have good nutrition for their development. This is confirmed by (Marwan, 2017), who states that one of the function of intertextuality is to provide a certain impression.

(2) Minion (Miniatur Layar Pinisi Lontara) Signature Souvenir of Butta Anging Mammiri Based on Cultural Acculturation of South Sulawesi (091004/2018/PKMK)

The title SCP in data (2) refers to the innovation of signature souvenirs of the Makassar area which has the aim to preserve and educate the public called, Minion. Promotes Makassar's distinctive culture which is famous for pinisi ships, thus making this product interesting and has its own uniqueness. The innovation was made in the form of a miniature that resembles pinisi ships by promoting the signature lontara writings of Makassar ${ }^{4}$.

The writing this SCP title is an adapted text from one of the 3D animated comedy films produced by Illumination Entertainment in 2010, namely Minions ${ }^{5}$. Both have intertextual relation that can be seen in the title, the noun Minion illustrates a souvenir made in the form of a miniature pinisi ship. It is well known that the meaning of miniature noun is an imitation of something on a reduced scale; or something small. This is the same as the depiction of Minions in the animated comedy film, namely as a small creature who is loyal to his master. The similarity is clearly found in the depiction of something in a small form or in other words as a miniature.

(3) Finding NEMO (Naptoquinone Ethyl Methoxycinnamate halel Opat) as an Antibacterial for Mycobacterium tuberculosis (063099/2018/PKMPE)

The phrase Finding NEMO in the title of SCP refers to Naptoquinone Ethyl Methoxycinnamate Halel Opat that is used as antibacterial agent for Mycobacterium tuberculosis. On further inspection, the phrase Finding NEMO is inspired from children animated film released in 2003 with the same title: Finding $\mathbf{N e m o}^{6}$. The intertextuality relationship between the two lies in the use of titles that have striking similarities. It aims to attract readers by bringing up the title

${ }^{4}$ https://web.facebook.com/pg/MINION_Miniatur-LAyar-Pinisi-Lontara165184004188575/posts/ on March 312020 at 11.38 Western Indonesian Time

${ }^{5}$ https://id.wikipedia.org/wiki/Minions on March 312020 at 11.47 Western Indonesian Time

6 https://id.wikipedia.org/wiki/Finding_Nemo on March 312020 at 12:57 Western Indonesian Time 
of Pixar's second most successful animated children's film. The SCP title Finding NEMO can be said to be the transformation text or adapted text from the Finding Nemo film, which is known that the film was previously released in May 2003.

(4) Elmo "Electronic Latex Modular Machine", Mechanization of the Latex Production Process: Efforts to Improve Partner Quality and Productivity of PT Perkebunan Nusantara IX (061031/2018/PKMT)

Data (4) shows the SCP title which refers to an electronic latex modular machine. A mechanization in producing latex as an effort to improve the quality and productivity of PT Perkebunan Nusantara IX's Partners. The writing of this SCP title is motivated by one of the animated characters in the children's television program series that combines educational programs packed with entertainment, Sesame Street. One of the muppet characters in Sesame Street that is loved by children is the character Elmo, a red-haired monster that targets the audience of toddlers? Intertextuality relationship is found in title that uses Elmo animated character as role model and inspiration. This can be seen prominently in the use of the Elmo character name in the title. The transformation process in writing the title in data (4), which is motivated by the title of the animated film, is done by combination of syllables, seen in the pattern of vocal-consonant-consonantconsonant-consonant-vocal-consonant-vocal-consonant (VCCCVCVC) in Electronic to Electronic, consonant-vocal-consonant-vocal-consonant (CVCVC) pattern in Modular to Mo-dular; thus the result is obtained as Elmo.

\subsubsection{Prior Text from Drama Genre}

Texts come as a form of influence from previous texts that already existed before. This indicates the existence of intertextuality relations that are closely intertwined in the SCP titles and drama genre. It is known that the genre of film that is much in demand by viewers in Indonesia is a film with a genre of romantic drama and comedy that presents a dramatic human story (Rubyasih, 2019). Here are a few drama films that came first with an influence on the formation of the SCP titles. It can be seen in the data below, the utilization of drama film genre which is used as prior text in the writing of SCP titles.

${ }^{7}$ https://id.wikipedia.org/wiki/Elmo on March 312020 at 13:26 Western Indonesian Time 
(5) SAH (Sterilisasi Air Hujan) Using Adsorbents by Utilizing the Content of Chitosan from Crab Shells Into Consumable Water (091002/2018/PKMPE)

The word $\boldsymbol{S A H}$ in the title of data (6) is an abbreviation from noun phrase Sterilisasi Air Hujan (Sterilization of Rain Water) which went through removal transformation. This can be seen in the combined results of each syllable: $\boldsymbol{S}$-terilisasi $\boldsymbol{A}$-ir $\boldsymbol{H}$-ujan, abbreviated as $\boldsymbol{S A H}$. This title refers to the tools used for rainwater sterilization by utilizing the chitosan content in crab shells. Later, this tool will sterilize rainwater into water suitable for consumption. It is known that chitosan in crab shells has a high effectiveness for adsorbent in purifying water, because it contains 3 types of amino acids, primary, and secondary hydroxy groups (Pala'langan, Sinardi, \& Iryani, 2017)'(Nuralam, Arbi, \& Prasetyowati, 2012).

Viewed from the level of intertextual relations, there is a striking similarity in the selection of $\boldsymbol{S A H}$ verb in the SCP title with one of the films titled Insya Allah Sah. This film is adapted from a novel written by Achi TM released in 2015 under the same novel title, Insya Allah Sah $^{8}$. This shows that the title $\boldsymbol{S A H}$ is a transformation text from film Insya Allah $\boldsymbol{S a h}$, which is already exist beforehand.

(Rahman, 2015) states that intertextuality relationship according to Angelika Neuwirth (an expert on Al-Qur'an and classical Arabic literature in the world) saw a prominent character in the findings of something different. This difference is clearly found in the meaning of the $\boldsymbol{S A H}$ which is contained in the SCP title with the title of the film and novel. In the title, $\boldsymbol{S A H}$ verb is an abbreviation for the noun phrase Sterilisasi Air Hujan that undergoes transformation. Whereas in the title of film and novel, the meaning of $\boldsymbol{S A H}$ is to describe a marriage being officially recognized by religion.

(6) GGS (Gelang Getar Sholat) Imam Motion Detection Tool to Increase the Devotion of Prayer of the Hearing Impaired (061002/2018/PKMKC)

The innovation in the title of SCP data (7) is in the form of aid of Gelang Getar Sholat (Vibrating Prayer Ring), abbreviated as $\boldsymbol{G} \boldsymbol{G S}$, specifically for people with hearing impairments. The $\boldsymbol{G} \boldsymbol{G S}$ functions as a detector for the Imam's prayer movement, which consists of two rings

${ }^{8}$ https://id.wikipedia.org/wiki/Insya_Allah_Sah on March 312020 at 13.34 Western Indonesian Time 
used for the imam and the congregation. The way it works is by sending a signal from the imam movement which is captured by a bracelet, then the signal will be sent to the follower bracelet which will cause vibrations ${ }^{9}$.

This SCP title was carefully viewed as having an intertextuality relationship with one of the soap opera shows produced by Amanah Surga Productions in 2014, namely Ganteng-Ganteng Serigala $(\boldsymbol{G G S})^{10}$. This soap opera show is also a story inspired by a romance fantasy film series adapted from a novel with the same title and author, Stephenie Meyer. Twilight novel was first released in 2005 which was then followed in the form of big screens. The sequence of the film series are: Twilight (2008); New Moon (2009); Eclipse (2010); Breaking Dawn Part 1 (2011); and Breaking Dawn Part 2 (2012)

The intertextuality relationship of the two lies in the male figure. It can be seen in the SCP title $\boldsymbol{G} \boldsymbol{G S}$, which is an abbreviation from clause $\boldsymbol{G}$-elang $\boldsymbol{G}$-etar $\boldsymbol{S}$-holat that is used by imam to lead prayer for the hearing impaired. "Imam" in The Great Indonesian Dictionary/KBBI (2012: 721) is interpreted as the leader of the course of prayer, in general, the prayer leader in congregation are men. But if there are no men, then a woman may be a leader as long as the followers are women.

Whereas in the soap opera title, GGS stands for $\boldsymbol{G}$-anteng-G-anteng $\boldsymbol{S}$-erigala. Adjective ganteng according to $K B B I$ (2012: 612) means the figure of a man with a beautiful face and dashing. It is clear that the title is used to designate men who have handsome stature as the characters, who happen to be werewolves and vampires as well. Likewise in the Twilight film and novel series, the main characters are handsome men who are also werewolves and vampires. So it can be concluded that the Twilight novel series is a hipogram from the Twilight film series, the Ganteng-Ganteng Serigala (GGS) soap opera, and the SCP title Gelang Getar Sholat (GGS).

\section{(7) Sambaran AADC (Sarana Baru Media Pembelajaran IPA Air Dry Clay) (041040/2018/PKMM)}

\footnotetext{
${ }^{9}$ http://unissula.ac.id/c24-beritaunissula/gelang-karya-mahasiswa-unissulapermudahdiasabilitas-sholat-berjamaah/ on April 12020 at 12:04 Western Indonesian Time

${ }^{10}$ https://id.wikipedia.org/wiki/GantengGanteng_Serigala on 1 April 2020 at 12:19 Western Indonesian Time

${ }^{11} \underline{\mathrm{https} / / / \text { id.wikipedia.org/wiki/Twilight (novel) }}$ https://translate.google.com/translate?hl=id\&sl=en\&u=https://en.wikipedia.org/wiki/The Twilight_Saga_film_series)\&prev=search on April 1 2020 at 13:15 Western Indonesian Time
} 
The media for learning using Air Dry Clay is an innovation created by Biology Education students at the Universitas Muhammadiyah Sukabumi, named Sambaran AADC ${ }^{12}$. This SCP title is a representation of the science learning media by using Air Dry Clay to make human organs and cell organelles. This media can provide innovations for teachers in junior and senior high schools in Sukabumi to create interesting learning media from materials that are easily available and harmless.

The writing of the SCP title involves a process of removal transformation and is aided by the creativity of the writer. This can be seen in the combined result of each syllable, in the clause Sarana Baru Media Pembelajaran IP-A A-ir D-ry C-lay, producing $\boldsymbol{A} \boldsymbol{A D C}$. Upon closer inspection, the title happens to be related to a romantic film by Rudi Soedjarwo released in $2002^{13}$, Ada Apa dengan Cinta? Which are also known as the abbreviation $\boldsymbol{A A D C}$. The form of intertextual relationship is located in the usage of the same abbreviation, which is $\boldsymbol{A A D C}$. The difference of both can be clearly seen in the meaning of the title. In the SCP title, $A \boldsymbol{A D C}$ is used to portray an innovation in learning media using Air Dry Clay. Whereas $\boldsymbol{A A D C}$ on the film title is used to portray romantic drama of high school students acted by Dian Sastrowardoyo and Nicholas Saputra.

(8) (LASKAR CIBUMI) Laskar Cinta Ibu Hamil Sebagai Gerakan Mahasiswa Peduli Ibu Hamil (001041/2018/PKMM)

The high MMR (maternal mortality rate) in pregnant women in the Semarang area is the reason for the implementation of the Laskar Cibumi activity. Based on data summarized by Indah, an Unnes student who initiated this idea, since 2015 it is known that the number of maternal deaths in the city of Semarang is still high. With the Laskar Cibumi activity, it is hoped that pregnant women have the knowledge and awareness of the importance of health to the mother during pregnancy ${ }^{14}$. The SCP title in data (10) is seen to be related to the film title that was released in

\footnotetext{
${ }^{12}$ https://id.scribd.com/document/441991025/Jurnal-Artikel-pdf on April 12020 at 13:38 Western Indonesian Time

${ }^{13}$ https://id.wikipedia.org/wiki/Ada_Apa_dengan_Cinta\%3F on April 12020 at 14:15 Western Indonesian Time

${ }^{14}$ https://www.suaramerdeka.com/news/baca/104402/tekan-risiko-aki-ibu-hamil-diberikan pendampingan on April 12020 at 20:15 Western Indonesian Time
} 
2008, Laskar Pelangi ${ }^{15}$. It is a film that was adapted from the novel of the same title, which was written by Andrea Hirata and published by Bentang Pustaka in $2005^{16}$.

The link between the two lies in the equation in using the Laskar noun in the movie title and the SCP title, used to describe the inspirational story of a group of people in an act of kindness. In the title of SCP, LASKAR CIBUMI means a group of students who make a movement to educate pregnant women in order to reduce the mortality rate of pregnant women by informing the importance of health during the pregnancy process. Whereas in the title of the film and novel, Laskar Pelangi is a story of enthusiasm and inspiration of a group of students in the village in Belitung in seeking knowledge even with limited conditions, which did not discourage them.

\subsubsection{Prior Text From Horror Genre}

Movies with a tense, frightening, and gruesome presentation have a special attraction for fans of the horror genre (Yoesoef, 2015). The use of horror film genre as an intertextual relationship appears in the writing of the SCP titles. This horror film genre serves to provide resources in the formation of the title that remains adapted to the context. The intertextuality relationship can be seen in the use of horror film title that has similarities with the SCP title, but they are still adjusted to the context and creativity of the writer. The following data shows the intertextual relationship between the SCP titles with horror film genre.

(9) Pengabdi Keong (Pemanfaatan Keong Sawah Berprotein menjadi Kecap Keong) (061009/2018/PKMK)

Paddy rice (golden apple) snails have high protein, including: $15 \%$ protein, $2.4 \%$ fat, $24 \%$ ash content (Nuralam et al., 2012). This good protein content can be used as a basis for making soy sauce. In general, soy sauce is made from soy ingredients, but not with this one. This encouraged students from Universitas Muria Kudus to utilize rice snails of fishery products to be processed into soy sauce as new and exciting innovations in the culinary world.

The writing the SCP title data (9) is clearly seen as a transformation or adaptation text from an Indonesian horror film released in 2017, which is remade from a film with the same title namely

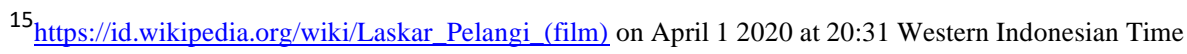

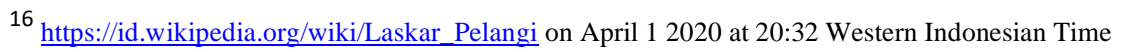


Pengabdi Setan (Devil's Servants) released in $1980^{17}$. The similarity can be seen in both using the noun Pengabdi (servant). The role of the film's title in relation to the writing of the SCP title is to provide resources for the reshaping of a text that remains adapted to the context. In the movie title, noun phrase Pengabdi Setan is used to portray a horror theme. Whereas in the SCP title, phrase Pengabdi Keong is the writer's creativity in describing innovations in utilizing rice snails to be used as raw material for making soy sauce.

\subsection{Discussion}

The results showed that there are three film genres that have intertextual relations with the writing of the SCP titles. The film genres include: (1) animation; (2) drama; and (3) horror. The film genres act as a reference text or prior text that comes before the formation of the SCP titles. Based on the results of the study, there are relevant comparisons between previous studies that can be made.

The difference in the results of this study in comparison to others stems from the title of SCP which is used with reference to the film genres as a prior text. As for the following research, poetry, music albums, diversity texts, humor texts, story texts, ideologies, novels and videos are used as data sources. (Septiaji, 2018) examines the intertextuality relationship between poem Atas Nama Cinta by Denny JA and Serat Kembang Raya by Fatin Hamama, et al. Intertextuality relations are seen in social conflicts that occur between characters in each story. (Batmang, 2019) examines the expressions of Amir Hamzah and Chairil Anwar shown in romantic poems. This can be seen from the intertextuality relationship between two concepts of love, including: (1) the concept of a lover in the poem "Dalam Matamu" by Amir Hamzah with the poem "Sajak Putih" by Chairil Anwar. (2) The concept of betrayal of lovers in the poem "Kusangka" by Amir Hamzah and the poem "Penerimaan" by Chairil Anwar. The position of the poems by Amir Hamzah serves as a reference text in the shaping of Chairil Anwar's poems, which are positioned as transformational texts.

(Fitriarti \& Monica, 2020) sees the existence of intertextuality in the character of Dewi Uma in the poem "U.M.A" by Putu Fajar Arcana. The poem is a text inspired by the story of Sudamala which is closely related to the wayang (shadow puppet) story. This is evident in the

${ }^{17} \underline{\text { https://id.wikipedia.org/wiki/Pengabdi_Setan_(film_2017) }}$ and https://id.wikipedia.org/wiki/Pengabdi_Setan_(film_1980) on April 12020 at 14:54 Western Indonesian Time

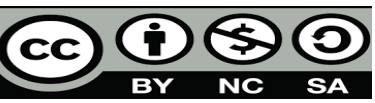


character of Dewi Uma who has close relations with Indonesian women who are required to have a gender perspective. (Septiaji, 2018) also examined the intertextuality relationship in the antalogy of the poem "Atas Nama Cinta" by Denny JA with the poem essay "Serat Kembang Raya" by Fatin Hamama, et al. Intertextuality relations are both built in the form of social conflict. It is believed that the existence of texts never stands alone, but through the influence of other texts.

(Hananto, 2019) considers that a study of works requires an understanding of other texts to facilitate the understanding of a work. This can be said that a text cannot be separated from other texts. Sticking to the concept, the research saw an intertextual relationship in the album "Viva La Vida" Coldplay with Eugene Delacroix's paintings as pictures from their album. (Iswanto, 2014) sees the intertextual relationship between the Kempalan Manuscript of the Islamic Scriptures collection by Soetanto in Sonobudoyo Museum. This relationship can be seen in the aspects of sharia / fiqh with aspects of sufism / essence which become guidelines in the Sultanate of Yogyakarta.

(Sukyadi, 2013) also notices, based on the ideas of Saussure, that the presence of a text is even broader in scope, namely, a science cannot stand alone. This can be stated that there is a relationship or connection with the text or other fields of study. The relationship can be seen either explicitly or implicitly. (Marwan, 2017) examine the existence of relationships between texts in religious humor texts. The functions of intertextuality in the discourse of humor are: to bring more life to old texts, explain the cultural context, deepen the topic of humor, refine the message, and give a certain impression.

(Rahayu, Abdullah, \& Udasmoro, 2015) also sees a comparison of the two Aladdin stories, the Arabian Nights version with the title "The Story of Aladdin and the Wonderful Lamp" with the animated film version of Walt Disney Feature Animation under the title "Aladdin" which was produced in 1992.

(Setiartin R., 2016) utilizes the text of folklore as a reference text that is transformed into a visual story as a learning activity for students. This transformation model involves the background knowledge, feelings, and life experiences of each student. (Purwantini, 2017) studies the novel Arok-Dedes which opposes the characterization of characters and events in the Pararaton folklore, whose presence had already existed beforehand. Deconstruction in the novel Arok-Dedes 
contains broadening or meaningful development. The results of study show that the Arok-Dedes novel was a social criticism of the New Order regime that used the Surat Perintah Sebelas Maret, symbolized by Dedes.

(Triyogo \& Wiryamartana, 2001) examines the intertextual relationship in the type of shadow puppet play, Banjaran Gathutkaca. Brajadenta Mbalela as a hipogram is considered as something standard. Hipogram transformation as something standard is used as a reference by compaction. This transformation process is a continuation of the story convention taken from the reference text into the new text. (Ulummudin \& Khikmatiar, 2019) examines the story of Noah in the Quran and the Bible using an intertextual approach. The difference in the story of Noah conveyed in the Quran and the Bible is seen in the theme. In the Quran the theme is monotheism or monotheistic teachings, while in the Bible the theme is human evil. It is known that the structure of the Quran contains many simplifications, so that the principle of haplology becomes dominant in each fragment.

(Kurniawati, 2018) examines Lu Xun's ideology in looking at the gender equality of Chinese women in Western values with traditional values. Lu Xun transforms Western and traditional Chinese values with the principle of Zong Yong (middle way) which is more in line with Chinese culture, as an effort to harmonize society and achieve women's emancipation. (Rahmatullah, 2019) observes the intertextuality of Muqātil's understanding (an early tafsir figure whose work is still intact today) who sees that a text cannot stand alone. The Quran text has an intertextual relationship with other texts, in this case the biblical text. The Bible as the word of God that came down before the Quran, in certain contexts has an attachment to meaning and content with the text of the Quran. In general, the relationship of Quran and Bible has are three typologies, namely: (a) positive appreciative tone; (b) being critical of the polemic; and (c) being neutral and tolerant.

(Perdana, Doyin, \& Mulyono, 2017) examines intertextual forms in novel Tembang Cinta Bumi Sunda (TCBS) by Aan Merdeka Permana and novel Gajah Mada Perang Bubat (GMPB) by Langit Kresna Hariadi, including: (1) expansion; (2) story reversal; and (3) transformation. (Kusuma, Waluyo, \& Wardani, 2018) discovers that novel "Padung Jiwa" by Okky Madasari is a hipogram from novel "Calabai" by Pepi Al-Bayqunie as transformational text. The similarity of 
themes, characterizations and events shows the intertextuality relationship between the two. As for the plot and setting in the novel "Calabai", it deviates from the hipogram.

(Panuju, 2019) finds intertextuality in the comment section of Youtube video titled "Jangan Panggil Aku Cina". The relationship of intertextuality is emphasized on the text permutation model with the results of the analysis that there are stereotypical views and prejudices that place ethnic Chinese as bad/hated ethnicity. (Mahliatussikah, 2017) finds that Laila Majnun's story was a hipogram from Romeo Juliet's story. Intertextual relations are seen from: (1) transformation; (2) demystification; and (3) story modification. Romeo Juliet story set up a high literary bar/standard from which of the work of Laila Majnun's story is based on.

\section{CONCLUSION}

Based on the results of the study, it can be concluded that there are three film genres that have intertextual relations in the writing of Student Creativity Program (SCP) titles. The film genres include: (1) animation; (2) drama; and (3) horror. Film as a reference text or prior text predates the formation of the SCP titles. The intertextual relationship between the two appears in the use of film genre as a reference text that has several similarities, namely: (a) the name of the character; (b) title; and (c) certain content that has an attached meaning. The utilization of film genres of animation and drama as reference texts has a high appeal in the writing of the SCP titles.

\section{REFERENCES}

A, Teeuw. 1984. Sastra dan Ilmu Sastra. PT Dunia Pustaka Jaya: Jakarta.

Batmang. (2019). Ekspresi Amir Hamzah dan Chairul Anwar dalam Puisi-Puisi Percintaan. Kandai, 15(2), 185-200. https://doi.org/10.26499/jk.v15i1.939

Efendi P. (2009). Dakwah melalui Film. Al-Tajdid, 1(2), 127-136. Retrieved from http://ejournal.iainpalopo.ac.id/index.php/tajdid/article/view/576

Fiske, J. (1987). Television Culture: Popular Pleasures And Politics (Studies In Communication Series). In Methuen \& Co. Ltd. https://doi.org/10.4324/9780203837153

Fitriarti, K., \& Monica, I. M. (2020). Analisis Intertekstual Karakter Dewi Uma di dalam Puisi "U.M.A." Karya Putu Fajar Arcana. Salaka, 2(1), 16-25.

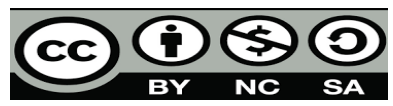


Hananto, B. A. (2019). Kajian Intertekstualitas Sampul Album ' Viva La Vida' dari Coldplay. Dekave, 12(2), 1-9. https://doi.org/10.24821/dkv.v12i2.3519

Hasbullah. (2014). Fenomena Intertekstualitas dan Klaim Orisinalitas. Jurnal Ilmu Budaya, 2(2), 377-384. https://doi.org/http://dx.doi.org/10.34050/jib.v2i0.2383

Iswanto, A. (2014). Syariat dalam Islam Jawa (Intertekstualitas Naskah Kempalan Kitab-Kitab Islam Koleksi Museum Sonobudoyo). Analisa, 21(02), 215-226. https://doi.org/https://doi.org/10.18784/analisa.v21i02.16

Kartika, R., \& Riyadi, T. (2011). Namestyle sebagai Pencitraan Visual Sebuah Film Animasi. Humaniora, 2(2), 1322-1328. https://doi.org/10.21512/humaniora.v2i2.3195

Kesuma, A., Novayelinda, R., \& Sabrian, F. (2015). Faktor-faktor yang Berhubungan dengan Perilaku Kesulitan Makan Anak Prasekolah. Jurnal Online Mahasiswa, 2(2), 953-961.

Krippendorff, K. (2004). Content Analysis: An Introduction to Its Methodology (Second Edition). In Sage Publications. Retrieved from https://login.proxy.libraries.rutgers.edu/login?url=http://search.ebscohost.com/login.aspx?di rect=true $\& \mathrm{db}=$ buh $\& A N=48779086 \&$ site $=$ ehost-live

Kurniawati, N. (2018). Prinsip Jalan Tengah “Zhong Yong” Lu Xun: Pendekatan Analisis Wacana Kritis. Kandai, 14(2), 269-286. https://doi.org/10.26499/jk.v14i2.791

Kusuma, K. A., Waluyo, H. J., \& Wardani, N. E. (2018). Pengakuan Calabai: Sebuah Analisis Intertekstual Novel "Pasung Jiwa" Karya Okky Madasari dan Novel "Calabai" Karya Pepi Al-Bayqunie. Kata, 02(01), 50-65. https://doi.org/https://doi.org/10.22216/jk.v2i1.3148

Mahliatussikah, H. (2017). Kritik Sastra Feminis dan Intertekstualitas dalam Kisah Layla Majnun dan Romeo Juliet. Prosiding Konferensi Nasional Bahasa Arab III, 501-514. Retrieved from http://prosiding.arab-um.com/index.php/konasbara/article/view/159

Marwan, I. (2017). The Function of Intertextuality in Religious Humor Text. Mozaik Humaniora, 17(1), 99-112.

Nuralam, E., Arbi, B. P., \& Prasetyowati. (2012). Pemanfaatan Limbah Kulit Kepiting Menjadi Kitosan sebagai Penjernih Air pada Air Rawa dan Air Sungai. Jurnal Teknik Kimia, 18(4), 14-20. https://doi.org/10.1210/jc.2006-1864

Pala'langan, T. A., Sinardi, \& Iryani, A. S. (2017). Studi Karakterisasi Kitosan dari Cangkang Kepiting Bakau (Scylla Olivacea) sebagai Penjernih Air pada Air Sumur. Prosiding Seminar Nasional Fakultas Teknik UNIFA, (November), 248-256.

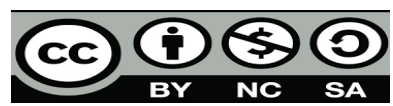


Panuju, R. (2019). Ajakan Rekonsiliasi yang Bertepuk Sebelah Tangan (Analisis Komentar Video "Jangan Panggil Aku Cina" di Youtube). KOMUNIKA: Jurnal Dakwah Dan Komunikasi, 13(2), 187-199. https://doi.org/10.24090/komunika.v13i2.1898

Perdana, D., Doyin, M., \& Mulyono. (2017). Intertekstualitas dalam Novel Tembang Cinta Bumi Sunda Karya Aan Merdeka Permana dengan Novel Gajah Mada Perang Bubat Karya Langit Kresna Hariadi. Jurnal Sastra Indonesia, 6(1), 7-13. https://doi.org/https://doi.org/10.15294/jsi.v6i1.14239

Purwantini. (2017). Dekonstruksi Struktur Penceritaan dalam Novel Arok-Dedes: Kajian Intertekstualitas. Atavisme, 20(2), 197-210. https://doi.org/10.24257/atavisme.v20i2.306.197-210

Purwanto, E., \& Yuliana, M. E. (2016). Penerapan Animasi Pertunjukan Wayang sebagai Media Pendidikan Budi Pekerti dan Memperkenalkan Budaya Bangsa kepada Anak Usia Dini. Jurnal SAINSTECH, 1(6), 21-31. https://doi.org/10.5802/aif.2338

Rahayu, M., Abdullah, I., \& Udasmoro, W. (2015). Pergeseran Nilai-Nilai Islam dalam Cerita Aladdin: Perbandingan "Arabian Nights" dan Film Animasi Disney. Er Harakah, 17(1), 5270.

Rahman, Z. A. (2015). Angelika Neuwirth: Kajian Intertekstualitas Dalam Qs. Al-Raḥmān Dan Mazmur 136. Empirisma, 24(1), 111-120. https://doi.org/10.30762/empirisma.v24i1.12

Rahmatullah. (2019). Hermeneutika Intertekstualitas Muqatil bin Sulayman. Jurnal Studi IlmuIlmu Al-Quran Dan Hadis, 20(2), 126-142. https://doi.org/10.14421/qh.2019.2002-01

Rubyasih, A. (2019). Uang Panai' Film Lokal yang Tembus Box Office (Persfektif Ilmu Komunikasi Terhadap Film “Uang Panai”). Al-Tadabbur: Jurnal Kajian Sosial, Peradaban, Dan Agama, 5(1), 1-11.

Septiaji, A. (2018). Intertextuality in Antology of Poetry Essay ( Research on Poetry Essay Atas Nama Cinta written by Denny JA and Poetry Essay Serat Kembang Raya written by Fatin Hamama, et al ). UICRIC 2018 (Unnes International Conference on Research Innovation and Commercialization 2018), 2019, 29-40. https://doi.org/10.18502/kss.v3i18.4695

Setiartin R., T. (2016). Transformasi Teks Cerita Rakyat ke dalam Bentuk Cerita Bergambar sebagai Model Pembelajaran Membaca Apresiatif. Litera, 15(2), 389-401.

Sukyadi, D. (2013). Dampak Pemikiran Saussure bagi Perkembangan Linguistik dan Disiplin Ilmu Lainnya. Parole, 3(2), 1-19.

Susanti, K., \& Raharja, D. M. (2017). Strategi Komunikasi pada Poster Film Cin(T)A sebagai

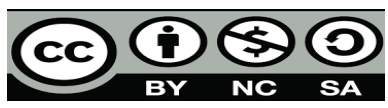


Daya Tarik. Jurnal Desain, 4(02), 85-91. https://doi.org/10.30998/jurnaldesain.v4i02.1151

Triyogo, Y. B. R., \& Wiryamartana, K. (2001). Hubungan Intertekstualitas dalam Banjaran Gathutkaca Karya Ki Nartosabdo. Sosiohumanika, 14(2), 323-334.

Ulummudin, \& Khikmatiar, A. (2019). Kisah Nabi Nuh dalam Alquran: Pendekatan Intertekstualitas Julia Kristeva. At-Tibyan: Jurnal Ilmu Alqur'an Dan Tafsir, 4(2), 209-226. https://doi.org/10.32505/tibyan.v4i2.1144

Wafi, A. (2019). Using Games to Improve Students' Active Involvement in the Learning of English Syntax at IAIN Madura: An Autonomous Learning. OKARA: Jurnal Bahasa Dan Sastra, 13(1), 107. https://doi.org/10.19105/ojbs.v13i1.2256

Yoesoef, M. (2015). Film Horor Sebuah Definisi yang Berubah. Wacana, Journal of the Humanities of Indonesia, 5(2), 1. https://doi.org/10.17510/wjhi.v5i2.322 